\title{
Drivers and Dynamics of Land Use Land Cover in Phewa Watershed, Kaski, Nepal
}

\author{
Sudip Raj Regmi ${ }^{1 *}$, Mahendra Singh Thapa ${ }^{1}$ and Raju Raj Regmi ${ }^{1}$ \\ ${ }^{1}$ Tribhuvan University, Institute of Forestry, Pokhara Campus, Nepal \\ *Corresponding author: sudipregmi7717@gmail.com
}

\section{Abstract}

Geospatial tools play an important role in monitoring Land Use Land Cover (LULC) dynamics. This study assessed the extent of LULC changes during 2003, 2010 and 2018 using temporal satellite imageries, computed the rate of change in area of Phewa Lake and explored the drivers of LULC change and lake area change in Phewa watershed. It used Landsat Imageries for 2003, 2010 and 2018 and carried out purposive household survey ( $\mathrm{N}=60$ ), key informant survey $(\mathrm{N}=5)$, focus group discussion $(\mathrm{N}=4)$ and direct field observation to explore the drivers of LULC change and lake area change. It generated LULC maps by using supervised classification and computed LULC change by applying post classification change detection technique. On screen digitization was done to find the area of Phewa Lake during 2010 and 2018. Agricultural land and urban areas were found to have increased by $11.63 \%$ and $1.46 \%$ respectively while forest area, barren land and water bodies were found to have decreased by $9.21 \%, 3.56 \%$ and $0.5 \%$ respectively between 2003 and 2010 . Forest area, urban areas and barren land were found to have increased by $5.9 \%, 3.28 \%$ and $5.02 \%$ respectively while agricultural landand water bodies were observed to have decreased by $7.83 \%$ and $0.16 \%$ respectively between 2010 and 2018. During 2010-2018, rate of change in lake area was found to have decreased by $0.61 \%$ with periodic annual decrement by 2.59 ha. The drivers responsible for LULC change were alternative form of energy, community forestry, promotion of private forestry, migration for foreign employment, inadequate market price of agricultural products, road construction, soil erosion and population pressure. Lake area was found to have decreased due to sedimentation, encroachment and road construction. Further study is important to know the exact contributions of these drivers of LULC change and lake area change for the sustainability of Phewa watershed.

Keywords: Geospatial,Land Use Land Cover, Phewa watershed, Landsat, Supervised

\section{Introduction}

Land use refers to the purpose that land is utilized while land cover is the combination of biological and physical condition of land (Steffen et al., 1992; Turner et al., 1995). Land use land cover (LULC) change refers to numerical change in a specified LULC either in increasing or in decreasing trend within the planet. Mouat et al. (1993) defined change detection as the phenomenon of finding numerical dynamics in a body or process by viewing it at different time periods. Land use land cover change (LULCC) is a changeable phenomenon which brings vital dynamics in environment on global scale (Emilio, 2010). Watershed condition can deteriorate due to improper LULC practices which impacts on soil, water resources, biodiversity, microclimate and declined $\mathrm{CO}_{2}$ absorption (Lambin et al., 2001) and affect natural resources (Awasthi et al., 2002). LULCC 
has negative impacts on weather patterns (Stohlgrenet et al., 1998) and generation of stream flow (Bronstert et al., 2002; Wang, 2001). LULCC has negative consequences on stream ecosystem structures and functions (Wang et al., 2000), its water quality parameters (Tang et al., 2005; Zampella et al., 2007) and quantity (White and Greer, 2006). Alkharabsheh et al. (2013) revealed that LULCC can be applied in many areas like research, planning, geography and policy formulation sectors. Changes in LULC practices have been regarded as one of the key influencing factors at present and many environmental problems are associated with the LULCC in the watershed. The study of LULCC helps to explain the interior mechanism of inter-activities of man-land environments. So, the study of LULC has been the backbone of integrated research of environment (Omernik et al., 1981).

As quantification of spatio-temporal process is not feasible by traditional techniques, temporal satellite imageries can be used to obtain important data for many GIS applications (Rawat and Kumar, 2015). These imageries can provide unavoidable information on land use analysis, soil, vegetation, various aspects of streams and its landforms (Borrough and McDonnell, 1998). At the same time Landsat imageries are mostly used in mapping and monitoring aspects due to their resolution characteristics and free availability (Sadidy et al., 2009). Geospatial techniques can play crucial role in examining, keeping and recovering biological, physical, social and economic aspects of watershed (Awasthi et al., 2002; Sidhu et al., 2000).

Phewa Lake is a master piece of nature in Pokhara city with national significance and is included in Lake Cluster of Pokhara Valley (included in Ramsar site in February 2, 2016). But human induced activities have negatively impacted on land use which result in deposition of sediments in water resources (Sthapit, 1988). These sediments decrease both depth and area of the lake which inturn affects its life span (Awasthi et al., 2007; Sthapit and Balla, 1998). The annual siltation rate of Phewa Lake has a range of about 175,000-225,000 $\mathrm{m}^{3}$ (Heyojoo et al., 2009) and at this rate of loss of $80 \%$ water volume, the terminal silt trap portion will be detached from the main body of the lake in upcoming 20-25 years and the lake will actually "die" in the following 135175 years (Sthapit and Balla, 1998). Deforestation, uncontrolled grazing and unsuitable farming caused landslides and erosion which in turn resulted in siltation in Phewa lake until mid-1970s (Fleming and Fleming, 2009; Paudyal et al., 2017b) and led to intensive heavy siltation in Phewa lake, the second largest lake and prominent tourist destination in Nepal (Paudyal et al., 2018).

Population rise, irregular economic growth and government policies supporting urban areas economic development are the major drivers of LULCC in Nepal (Jorgensen and Volleweider, 1989; Rimal et al., 2018 a; Rimal et al., 2018b). Mainly soil 
erosion, deforestation, unplanned rural road construction and rapid changes in LULC are degrading Phewa watershed (Regmi and Saha, 2015).

Therefore, for sustainable development and management of the watersheds, spatial inventories of the trends of LULCC and their prediction status are vital (Regmi and Saha, 2015). So this paper assesses the extent of LULC changes during 2003, 2010 and 2018 using temporal satellite imageries, computes the rate of change in area of Phewa Lake during 2010 and 2018 and explores the drivers of the change of LULC and lake area in Phewa watershed. Understanding LULC dynamics of Phewa watershed plays a vital role in designing proper land use plan for sustainable productivity and benefits. Therefore, this paper, with its information on potential environmental impacts, can be important for formulating policies and planning strategies for effective land management for the sustainability of Phewa watershed and Phewa Lake.

\section{Materials and Methods}

\section{Study Area}

Phewa watershed is situated in the south-western corner of Kaski district covering rural as well as urban area.

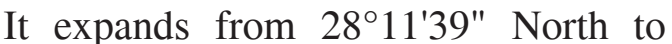
$28^{\circ} 17^{\prime} 25^{\prime \prime}$ North latitude and 83०47'51" East to $83^{\circ} 59^{\prime} 17^{\prime \prime}$ East longitude. The altitude of the area varies from 789 to 2508. $81 \mathrm{~m}$ above $\mathrm{msl}$ in the west with the highest peak at Panchase which is biologically rich. The watershed area

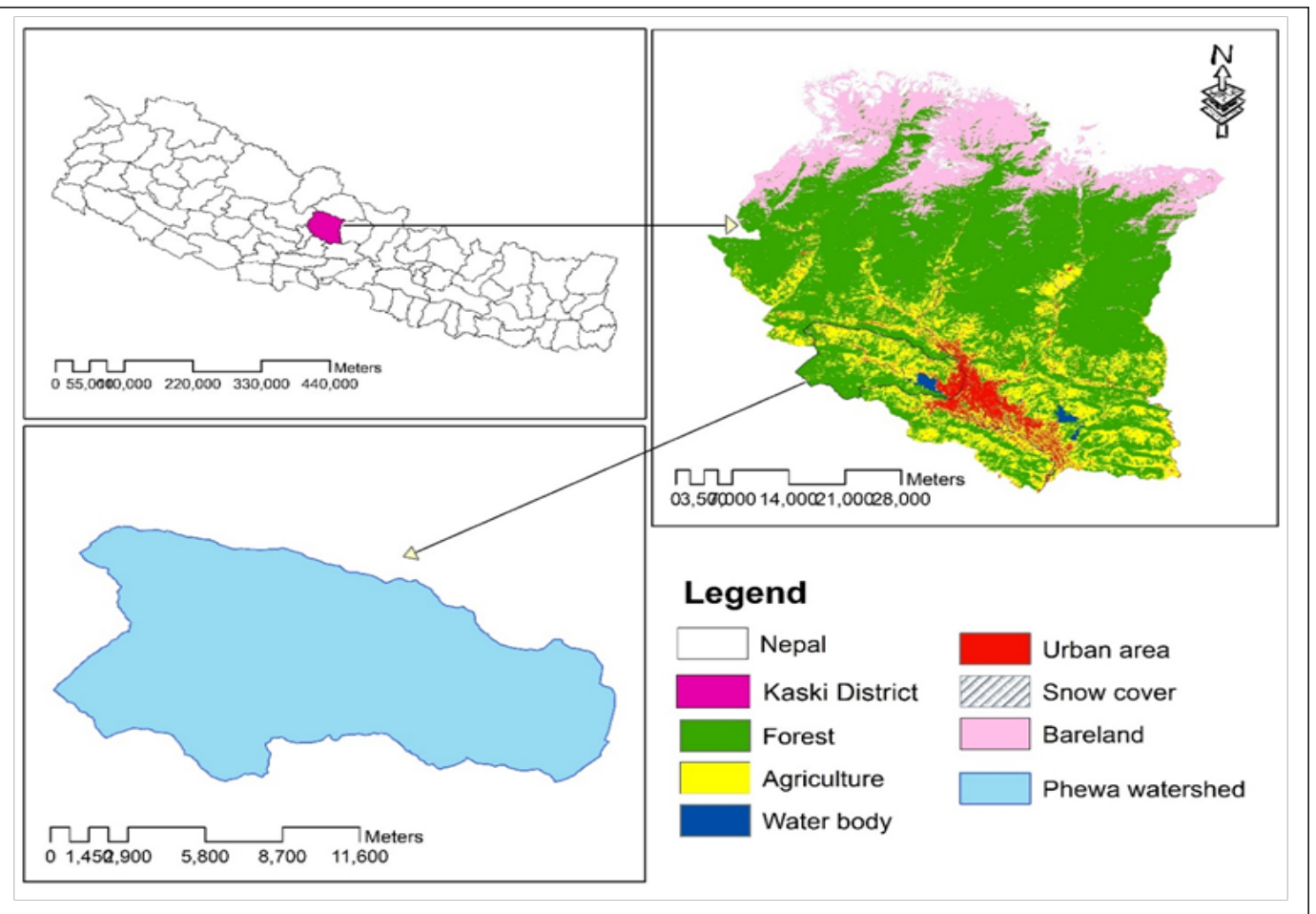

Figure 1: Map of the study area 
possesses moderate subtropical to the cool temperate type of climate.

Phewa Lake extends from 835' $44^{\prime \prime}$ to $83^{\circ} 58^{\prime} 10^{\prime \prime}$ East latitude and from $28^{\circ} 11^{\prime} 44^{\prime \prime}$ to $28^{\circ} 13^{\prime} 40^{\prime \prime}$ North longitude with average elevation of $794 \mathrm{~m}$ from mean sea level.
Landsat TM for 2003, 2010 and OLI_ TIRS for 2018 imageries was analyzed for assessment of LULCC. The LULC classes used for the classification were forest, agricultural land, barren land, water bodies and urban areas.

Table 1: Data specification of satellite imageries used in LULC classification

\begin{tabular}{|c|c|c|c|c|c|c|c|}
\hline Satellite & Years & Sensor & $\begin{array}{c}\text { Total } \\
\text { bands }\end{array}$ & $\begin{array}{c}\text { Temporal } \\
\text { resolution }\end{array}$ & $\begin{array}{c}\text { Spatial } \\
\text { Resolution (m) }\end{array}$ & $\begin{array}{c}\text { PAN } \\
\text { Band }\end{array}$ & $\begin{array}{c}\text { Date of } \\
\text { acquisition }\end{array}$ \\
\hline Landsat 5 & 2003 & TM & $1-7$ & 16 days & $30 * 30$ & Nil & 30-Nov-2003 \\
\hline Landsat 5 & 2010 & TM & $1-7$ & 16 days & $30 * 30$ & Nil & 1-Nov-2010 \\
\hline Landsat 8 & 2018 & OLI_TIRS & $1-11$ & 16 days & $30 * 30$ & $15 \mathrm{~m}, \mathrm{~B}-8$ & 23-Nov-2018 \\
\hline
\end{tabular}

\section{Methods}

The primary data related to the drivers of LULC change were collected through direct field observation, purposive household survey $(\mathrm{N}=60)$, key informant interview $(\mathrm{N}=5)$ and focus group discussions $(\mathrm{N}=4)$ while the secondary data viz Landsat TM for 2003, Landsat TM for 2010 and Landsat OLI_TIRS for 2018 imageries were freely downloaded from USGS website (earthexplorer.usgs.gov). Aster DEM from USGS website (earthexplorer. usgs.gov) was used for boundary demarcation of the watershed.

\section{LULC Analysis}

Radiometric, Atmospheric and Sun angle corrections of respective Landsat imageries were carried out. LULC maps for change detection analysis were generated using supervised classification with maximum likelihood classifier (Lillesand et al., 2004). Digital supervised classification of

\section{Rate of Change in Lake Area}

The rate of change in lake area was assessed by the given formula.

Rate of Change $(\%)=\left[\left((\mathrm{b} / \mathrm{a})^{\wedge}(1 / \mathrm{n})-\right.\right.$ 1)*100] (UNDP, RFDTh and FAO cited by Lamichhane, 2008).

$\mathrm{PAI}=\mathrm{A} \mathrm{i}+\mathrm{n}-\mathrm{Ai} / \mathrm{n}$

Where,

$\mathrm{a}=$ base year data

$\mathrm{b}=$ end time data

$\mathrm{n}=$ number of years

A $i+n=$ Area of $(i+n)^{\text {th }}$ year

$\mathrm{Ai}=$ Area of $i^{\text {th }}$ year

$\mathrm{PAI}=$ Periodic annual increment

\section{Data Processing and Analysis}

LULC change operation was done in ArcMap 10.3. On screen digitization was done to find the area of Phewa Lake during 2010 and 2018 in ArcMap 10.3. The rate of change in lake area was calculated by above formula. Quantitative data of LULCC and lake area change were analyzed using MS 
Table 2: LULC classes used for classification

\begin{tabular}{|c|l|l|}
\hline S.N. & LULC types & \multicolumn{1}{c|}{ Description } \\
\hline 1. & Forest & Shrub lands,trees, grassland bushes. \\
\hline 2. & Agricultural land & $\begin{array}{l}\text { Cultivation in sloping mountainous areas in terraced fields. Includes } \\
\text { both valley and terrace agriculture. }\end{array}$ \\
\hline 3. & Barren land & $\begin{array}{l}\text { Sandy areas, areas exposed after landslides and soil erosion. Quality } \\
\text { of soil is poor. }\end{array}$ \\
\hline 4. & Urban areas & Urban and rural human settlement areas. \\
\hline 5. & Water bodies & Areas with lake and rivers. \\
\hline
\end{tabular}

Excel 2016.The drivers associated with by forest which covered 4963.05 ha LULC change and lake area change of Phewa watershed were analyzed on MS Excel 2016.

\section{Results}

\section{LULC Dynamics of 2003, 2010 and 2018}

The area statistics of LULC for the respective time periods are shown in (Annex 1 and 2 and shown in Figure 2 (A), (B) and (C). There were drastic changes in LULC during these periods in the watershed. Agricultural land covered the largest area in all time periods followed by forest area in study time periods. In 2003, agricultural land covered 5179.86 ha $(43.2 \%)$ followed $(41.39 \%)$. Barren land, water bodies and urban areas covered 891.99 ha (7.44\%), 529.29 ha $(4.41 \%)$ and 425.34 ha $(3.55 \%)$ respectively. In 2010, agricultural land covered an area of 6573.78 ha $(54.83 \%)$ followed by forest which covered 3882.42 ha $(32.38 \%)$. Urban areas, water bodies and barren land covered 600.03 ha (5\%), 468.99 ha $(3.91 \%)$ and 464.31 ha $(3.87 \%)$ respectively. In 2018, the agricultural land covered 4914.72 ha $(40.99 \%)$ followed by forest which covered 4565.88 ha (38.08\%). Barren land, urban areas and water bodies covered 1065.87 ha $(8.89 \%), 993.33$ ha $(8.28 \%)$ and 449.73 ha $(3.75 \%)$ respectively.

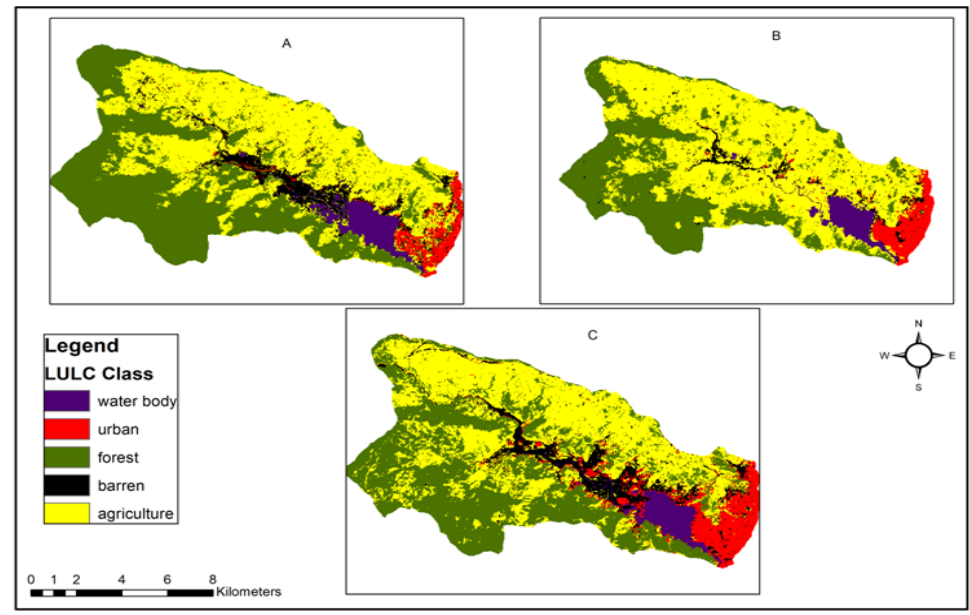

Figure 2 : LULC map for (A) 2003, (B) 2010 and (C) 2018 


\section{Accuracy Assessment}

Altogether 160 ground truth positions were collected with the help of Google earth image for 2003 and 2010. Additional GPS points combined with Google earth image were utilized to collect ground truth positions of classified LULC map for 2018. Confusion matrix was used for accuracy assessment. The overall accuracy of the classified maps was $85 \%, 92.44 \%$ land use was changed from forest to agricultural land by $12.01 \%$, barren land to agricultural land by $5.3 \%$, agricultural land to forest by $3.62 \%$, urban areas to agricultural land by $0.28 \%$ and water bodies to agricultural land by $0.81 \%$ (Annex 3).

The change/no change map for 20102018 (Figure 4) shows that the land use was changed from agricultural land to forest by $9.72 \%$, forest area to

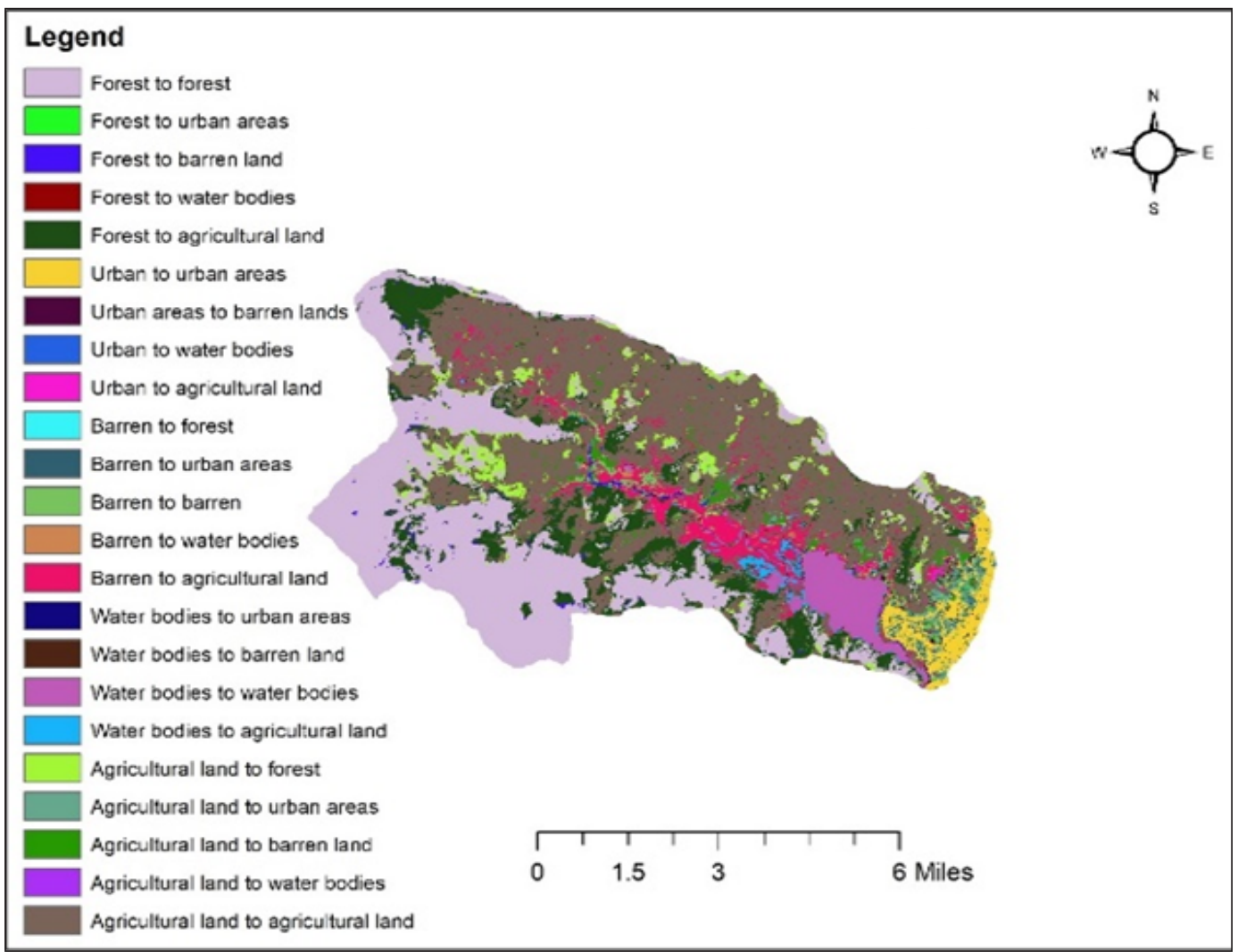

Figure 3 : Change/No change map during 2003 to 2010

and $88.1 \%$ respectively. The Kappa agricultural land by $3.79 \%$, barren land coefficients were $0.76,0.9$ and 0.84 to agricultural land by $1.22 \%$, urban respectively.

As shown in change/no change map areas to barren land by $0.39 \%$ and water for 2003-2010 is shown in (Figure 3) bodies to urban areas by $0.26 \%$ (Annex 4). 


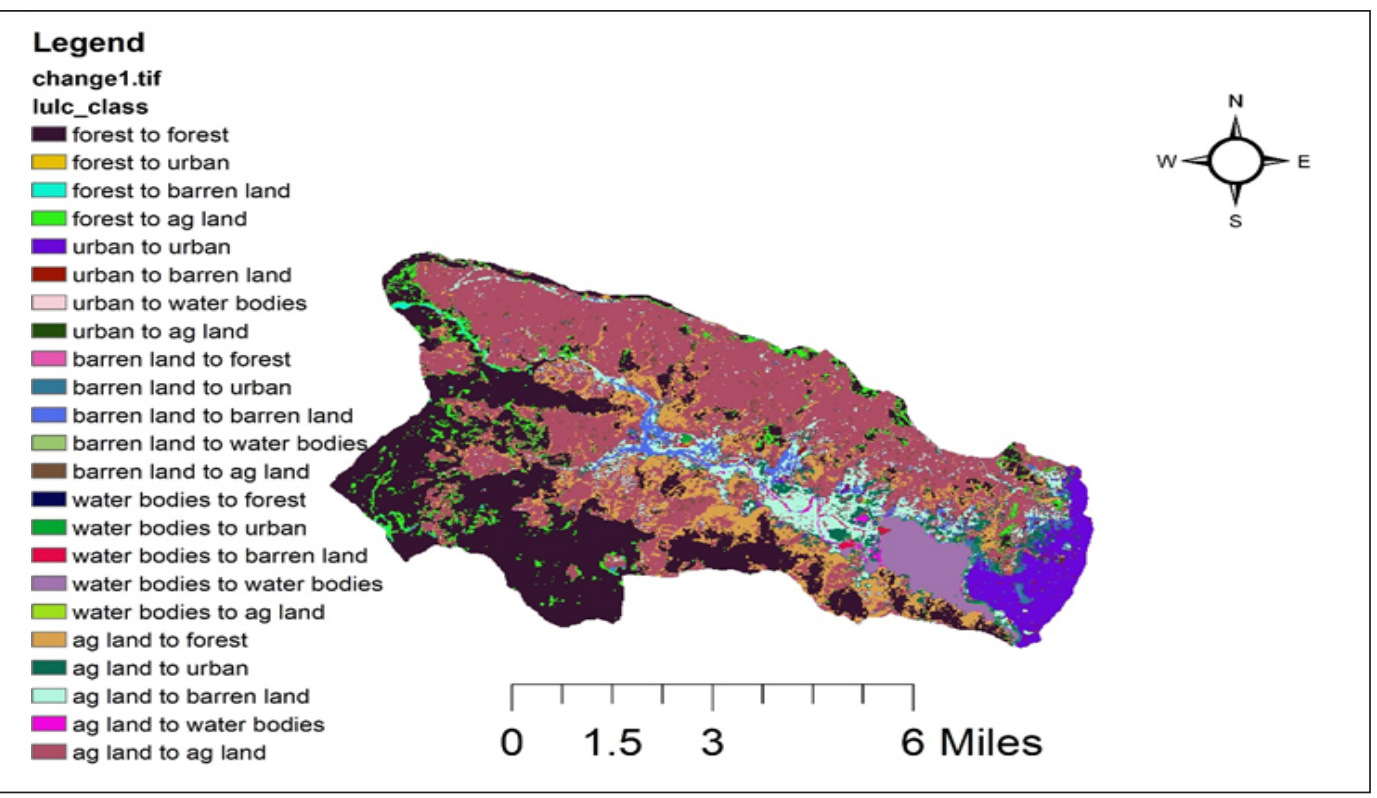

Figure 4 : Change/No change map during 2010 to 2018

Computation of the rate of change in area of Phewa Lake

\section{Legend}

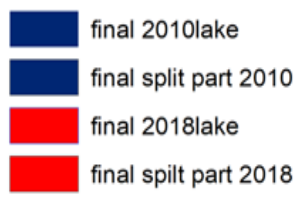

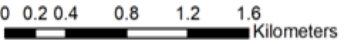

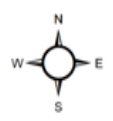

Figure 5 : Lake area change map

From the on screen digitization of The Normalized Difference Water Index Phewa Lake, we found that the lake (NDWI) ranges were -0.641791 to area was 430.64 ha in 2010 while it 0.419355 and -0.414176 to 0.0906588 was 409.92 ha in 2018 (Figure 5). The in 2010 and 2018 respectively (Figure periodic annual decrement was 2.59 ha. The rate of change in lake area was found to be $-0.61 \%$.

$6)$. Water bodies were degraded as there was decrease in positive value of NDWI between 2010 and 2018. 


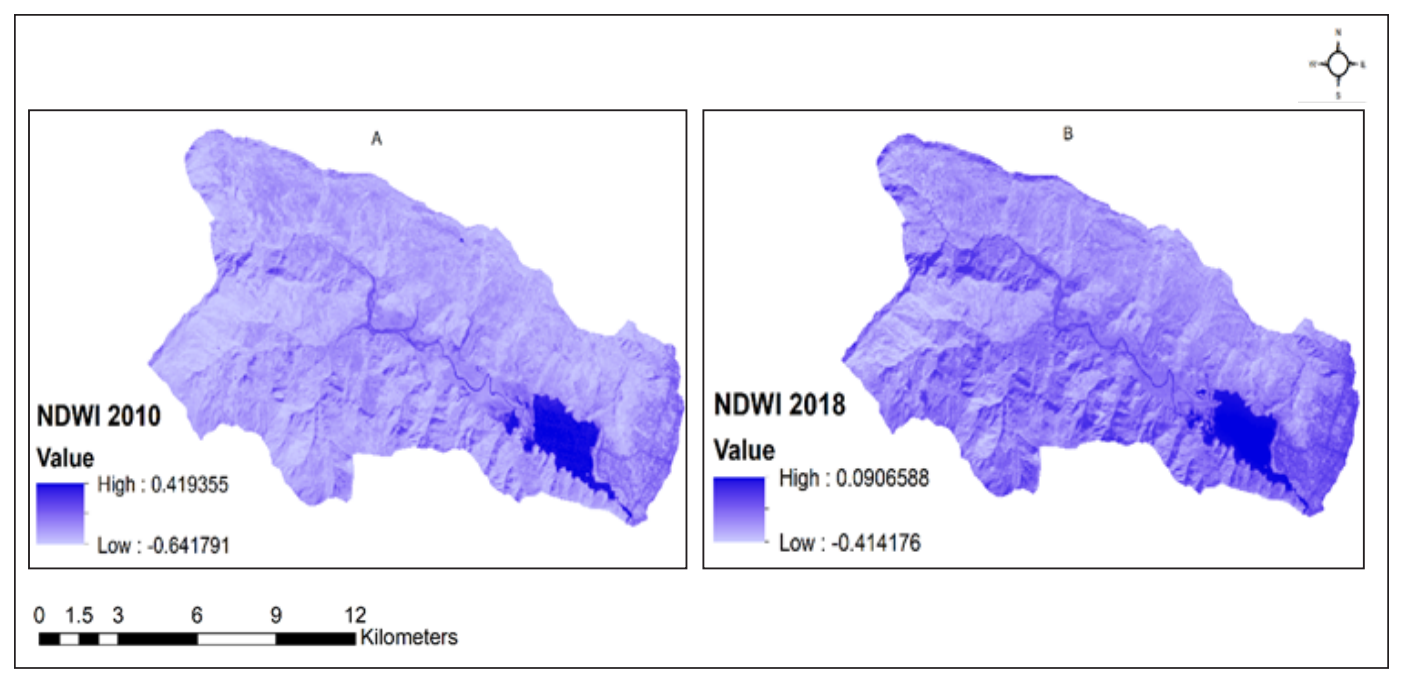

Figure 6: NDWI value range in (A) 2010 and (B) 2018

Drivers of LULC change and lake area change in Phewa watershed during 2010 to 2018

\section{Increase in forest area}

As per the opinion of respondents, the major drivers responsible for forest area increase were Community Forestry land (11\%)(Figure 7).

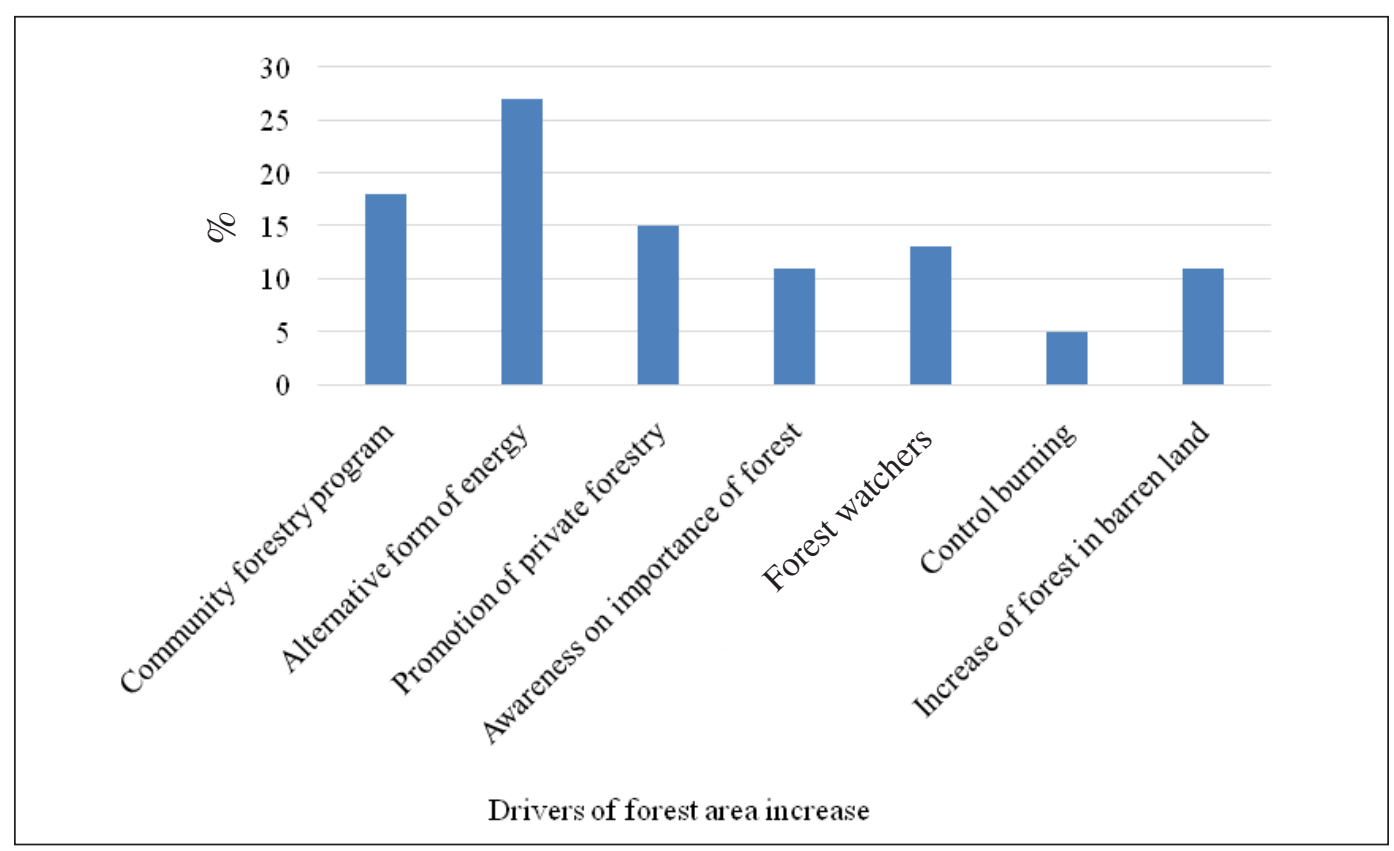

Figure 7: Respondents opinion on drivers of forest area increase 


\section{Increase in barren land}

As per the view of respondents, the major drivers for barren area increase were lack of manpower (42\%), road construction (13\%), soil erosion / landslides (16\%), lack of market price of agricultural products (20\%) and lack of irrigation facilities (9\%) (Figure 8). were population pressure $(69 \%)$ and migration to down stream areas $(31 \%)$ (Figure 9).

\section{Decrease in agricultural land}

As per the view of respondents, the major drivers for decrease in agricultural land were soil erosion / landslides (9\%), migration for

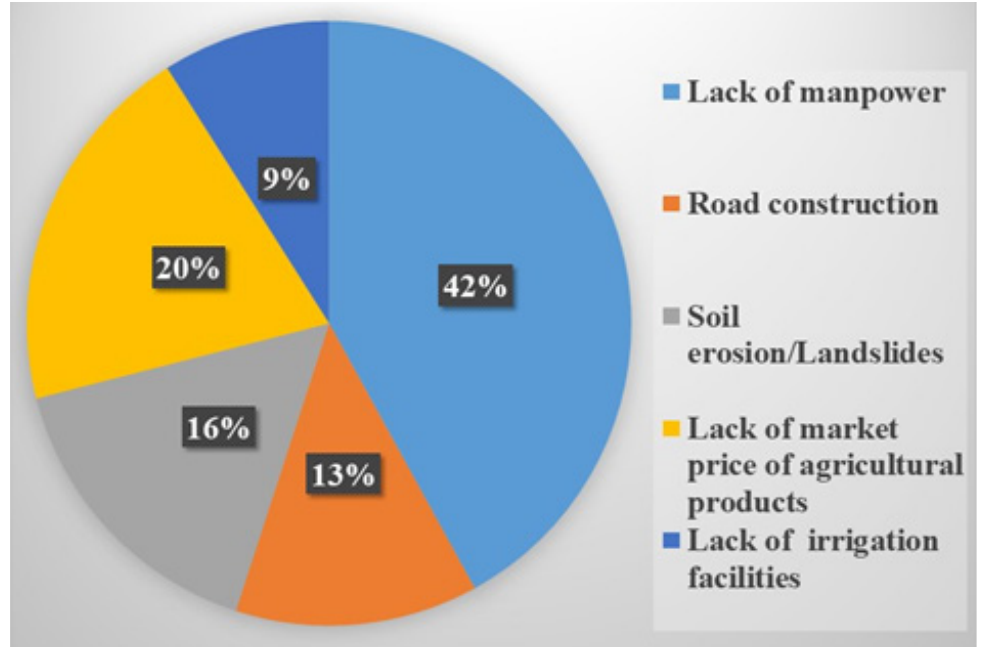

Figure 8: Respondents opinion on drivers of barren land increase

\section{Increase in urban areas}

As per the view of respondents, the major drivers for urban area increase foreign employment (33\%), road construction (10\%), lack of market price of agricultural products

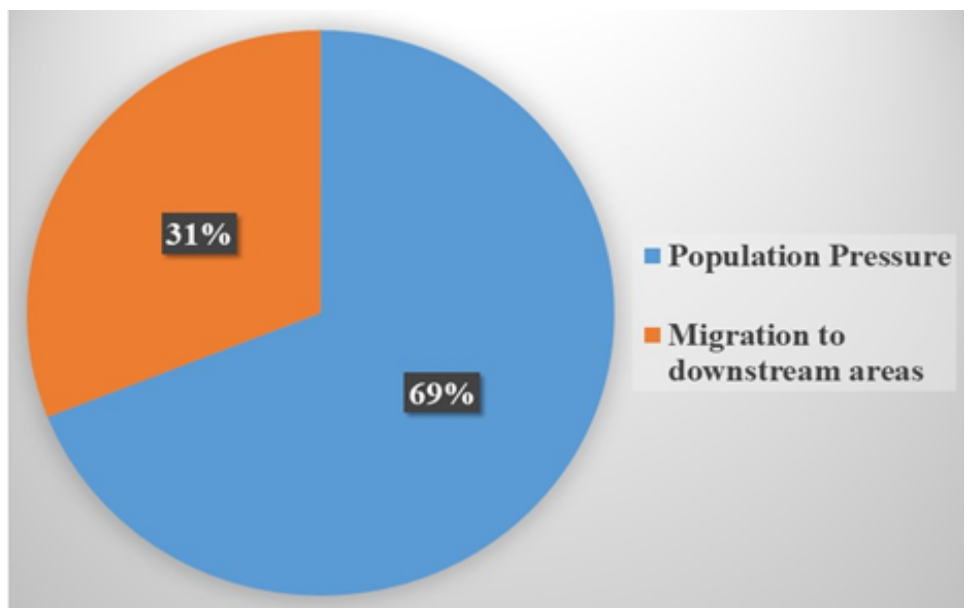

Figure 9: Respondents opinion on drivers of urban area increase 
(15\%), urbanization / infrastructures

$(11 \%)$, irrigation problem $(8 \%)$ and excessive use of chemical fertilizers (14\%) (Figure 10).
Discussion

Increase in forest area

Regmi and Saha (2015) have found that dense forests have decreased during the

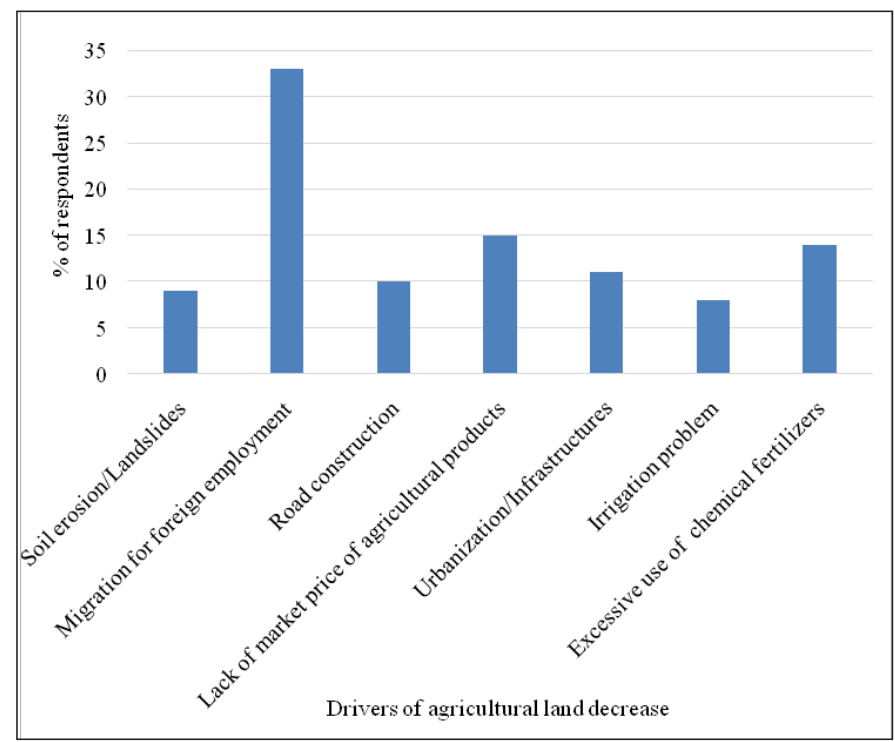

Figure 10 : Respondents opinion on drivers of agricultural land decrease

\section{Decrease in lake area}

As per the opinion of respondents, the major drivers responsible for decrease in lake area were sedimentation/soil erosion $(45 \%)$, encroachment around the lake $(24 \%)$ and road construction $(31 \%)$ (Figure 11). study periods 2000, 2005 and 2010 and the prediction of 2015 and 2020. They have also observed that medium to fairly dense forests and open forests have increased during these study periods and predicted periods. Our study also shows appreciable increase in forest

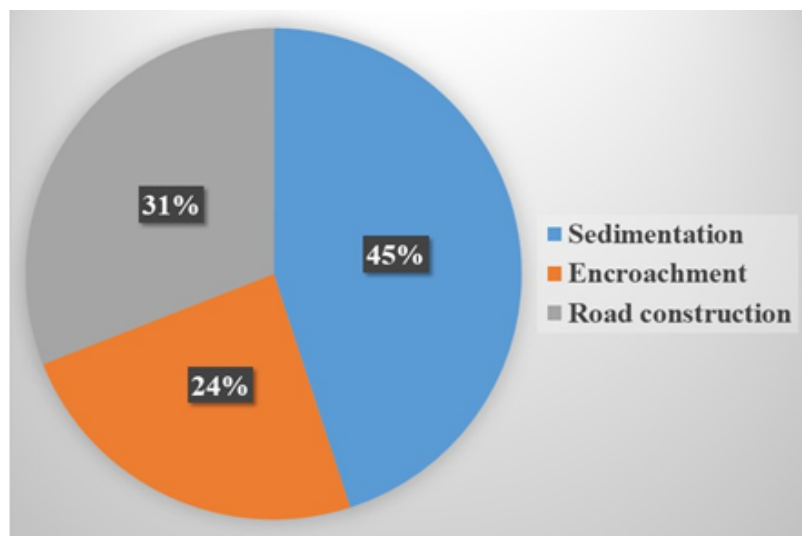

Figure 11: Respondents opinion on drivers of lake area decrease 
area of 683.46 ha during 2010 to 2018 . Also, more increasing trends in the area were observed under medium to fairly dense forests because of afforestation activities undertaken in large areas under community forest management program implemented in the watershed from mid-1990 as part of Nepal's national program. The agricultural lands can also be considered to have contributed in the increase of forest area in the study area (Annex 4). Local people's participation was noticed after emergence of community forestry in late 1970s and there was considerable increase in forest cover in degraded forest area as they were granted legal rights to utilize forest resources independently (Cronkleton et al., 2017; Paudyal et al., 2017a). There was transformation of eroded pasture, croplands and shrub lands to forestland which resulted in forest rehabilitation (Gautam et al., 2004; Niraula et al., 2013). There is overall increasing trend for uncultivated land, forest and waste land and declining shift of agricultural land in all sub-watersheds of the study area (Javed et al., 2009).

\section{Increase in urban areas}

Bhandari (2012) and Khanal and Bastola (2005) have observed that LULC changes and socio-economic dynamics have positive relationship. Rising pressure for energy and food for increasing population results in negative effects on sectors like farmland, grazing land, fuel wood and urban areas. Increase in built-up area was attributed to spatial expansion of existing builtup lands and increasing number of new rural and urban settlements due to high population growth. During 2010-2015, the urbanization rate of Pokhara was $5.21 \%$ (UNDESA, 2014). Muzzini and Aparicio (2013) have revealed that fast urbanization can be seen in Pokhara, which was a huge town of mid hill. After declaration of municipality and headquarter of western development region, rapid urbanization can be marked in Pokhara Valley (Rimal, 2011). Regmi and Saha (2015) have explained that population of the Phewa watershed is 198,333 with an average density of 665 persons per $\mathrm{km}^{2}$. These support our finding that urban areas have increased during our study.

\section{Decrease in agricultural land}

The decrease of agricultural land can be attributed to transformation of some portions of this land into forest, barren lands and development of new urban areas (Annex 4). The agricultural land decreased due to socio-political uncertainty, accessible off-farm earning in towns, declining agricultural productivity, lack of labor, dwindling earning from farming and geographical nearness to towns (Paudel et al., 2012; Paudel et al., 2014; Tamang et al., 2014).

\section{Decrease in lake area}

Sedimentation has a major role in the decrease of lake area. Natural disaster like soil erosion and debris flows are common in Andheri Khola - a major 
source of sediment to Phewa Lake (GON, 2015). Harpan Khola, Seti Canal, Phirke Khola and Bulanudi deposit sediments in Phewa Lake whose accumulation rate is in increasing trend. Heyojoo and Takhachhe (2014) have explained that sediment deposition in the lake is induced by human activities like haphazard road construction and unsuitable land use practices in both upstream and downstream areas in the watershed. They have found that the annual decrease rate of the lake was $0.46 \%$ with mean annual decrease in lake area around 2 ha (less than 10 ha), while our study shows the annual decrease rate of the lake as $0.61 \%$ with the mean annual decrease in lake area as 2.59 ha (Figure 5). This slight variation can be due to low spatial resolution of Landsat imageries for on screen digitization, different study periods considered and also because many drivers of the decrease in Phewa Lake can be more intensive now than before. Shrestha et al. (2004) have found that extreme soil erosion is induced bythe factors like land slope, deforestation, uncontrolled grazing, livelihood support farming and population growth combined with high rainfall. All these drivers are controlling the soil erosion phenomenon in Phewa watershed of Nepal.

LULC is a very dynamic phenomenon and there is trade off between LULC classes. Resettlement and land abandonment, alteration in land tenure policy, rapid urban growth and population rise are the dominant factors of LULCC in the mid hills of
Nepal (Bajracharya et al., 2014; Paudel et al., 2017; Rimal et al., 2015). The conventional farmers who cannot fulfill the requirements of their households prefer to migrate from that area and gradually leave farming in their agricultural land. Gautam et al. (2003) studied Roshi watershed of Kavre district and found that the drivers responsible for LULCC were emergence of community forest and accessibility of off farm earning. Barros (2004) has observed that increase in population and urban areas, less availability of land, demand for additional production and modification of technologies are the drivers of LULC in the world in present situation.

Deforestation, uncontrolled grazing, commercial farming, population growth, over cultivation and rural development policies are the major factors for soil erosion in the middle mountain of Nepal (Shrestha, 1997; Tamrakar, 1993). Bygone and present farming activities, topography in the mountains and hills, severe rainfall and fast urban growth are the major drivers of destructive soil erosion in the Phewa watershed (Awasthi, 2004; Bhandari, 2012).

The reasons behind LULC dynamics were related to the lack of integrated LULC management policies and heterogeneity in the socio-economic conditions of the watershed. This was also revealed by many researchers in their studies (Awasthi, 2004; Khanal and Bastola, 2005; Poudel, 2000; Sharma, 
2012). They have also observed that the lack of appropriate land use laws, policies and by laws is responsible for LULCC in Phewa watershed. Similarly, land tenure systems and government policies have also been considered as the main drivers of LULC dynamics in Phewa watershed.

\section{Conclusion}

The assessment of LULCC of Phewa watershed in western Nepal and its associated drivers was performed using geospatial tools and social survey techniques. The use of temporal satellite imageries is very useful, time saving and cost effective for the generation of LULC maps and change detection process.

There was a drastic change in LULC in Phewa watershed during the study periods. The obtained LULC maps summarized the highest coverage in the study area by agricultural land and forest followed by other three LULC classes in all study periods. Agricultural land and urban areas were found to have increased by $11.63 \%$ and $1.46 \%$ respectively while forest area, barren land and water bodies were found to have decreased by $9.21 \%, 3.56 \%$ and $0.5 \%$ respectively between 2003 and 2010. Forest area, urban areas and barren land had increased by $5.9 \%, 3.28 \%$ and $5.02 \%$ respectively while agricultural land and water bodies were observed to have decreased by $7.83 \%$ and $0.16 \%$ respectively between 2010 and 2018 . The analysis of change process using Landsat imageries showed compromise among various LULC classes.

Phewa Lake is an important tourism asset with its economic, socio-cultural and ecological significance. During 2010-2018, the rate of change in lake area was found to have decreased by $0.61 \%$ with periodic annual decrement by 2.59 ha. In the western part of the lake, there is decrease in are are sulting in detachment of a part of lake from its main body. Phewa watershed consists of plenty natural resources but due to various drivers they are at severe risk. The drivers responsible for LULC change in Phewa watershed were alternative form of energy, community forestry, promotion of private forestry, migration for foreign employment, inadequate market price of agricultural products, road construction, soil erosion and population pressures. Lake area was found to have decreased due to sedimentation, encroachment and road construction. Various biophysical and socio-economic drivers were dominating LULC dynamics in the study area.

Thus, application of geospatial tools should be expanded for natural resource management and it's monitoring for up to date updates. Further study is important to know the exact contributions of these drivers of LULC change and lake area change for the sustainability of Phewa watershed.

\section{Acknowledgements}

We are grateful to all reviewers and editors for their valuable suggestions during the finalization of the paper.We 
would like to thank Bibek Subedi, Sharad Thapa, Bhuwan Singh Bist and Pawan Karki for their help and encouragement. We appreciate respondents of study area for their support and cooperation during our field visit.

\section{Conflict of Interest}

The authors declare no conflict of interest.

\section{References}

Alkharabsheh,M.M., Alexandridis, T.K., Bilas, G.,Misopolinos, N.\&Silleos, N. 2013. Impact of land cover change on soil erosion hazard in northern Jordan using remote sensing and GIS.Procedia Environmental Sciences, 19,912-921. Doi:10.1016/j.proenv.2013.06.101.

Awasthi, K. D. 2004. Land use change effects on soil degradation, carbon and nutrient stocks and greenhouse gas emission in mountain watersheds. Ph.D. thesis, Norwegian University of Life Science, Abs, Norway.

Awasthi, K.D., Regmi, R.R., Pradhan, B.M., Singh, A., Sitaula,B. K. \& Kafle, G. 2007. Land Use change in Rupa Lake Watershed and Lake Area Shrinkage: A GIS/RS Approach.

Awasthi, K. D., Sitaula, B. K., Singh, B. R. \& Bajracharya, R.M. 2002. Land-use changes in two Nepalese watersheds: GIS and Geomorphometric analysis. Land Degradation and Development, 13(6), 495-513.Doi:10.1002/ldr.538.

Bajracharya, S., Maharjan, S., Shrestha, F., Bajracharya, O.\& Baidya, S. 2014. Glacier status in Nepal and decadal change from 1980 to 2010 based on Landsat data.Kathmandu:ICIMOD.

Barros, J.X. 2004. Urban growth in Latin American cities-Exploring urban dynamics through agent-based simulation (Doctoral dissertation, University of London).

Bhandari, K. P. 2012. Participatory GIS for Soil Conservation in Phewa Watershed of Nepal. ISPRS - International Archives of the Photogrammetry, Remote Sensing and Spatial Information Sciences, Volume $\quad$ XXXIX (B8),231236.Doi: $\quad$ 10.5194/isprsarchivesxxxix-b8-231-2012.

Borrough, P.A. \& McDonnel, R.A.1998. Principles of Geographical Information System. Oxford University Press. Oxford.

Bronstert, A., Niehoff, D. \& Bürger, G. 2002. Effects of climate and land: use change on storm runoff generation: present knowledge and modelling capabilities. Hydrological processes, 16(2), 509-529. Doi:10.1002/hyp.326.

Cronkleton, P., Artati, Y., Baral, H., Paudyal, K., Banjane, M.R., Liu, J.L., Tu, T.Y., Putzel, L.,Birhane, E.\& Kassa, H.2017. How do property rights reforms provide incentives for forest landscape restoration? Comparing evidence from Nepal, China and Ethiopia. InternationalForestryReview, 19 (4),823.doi:10.1505/146554817822295957

Emilio, F.M. 2010. Environmental social science: human-environmental interactions and sustainability. Chichester, UnitedKingdom: John Wiley and Sons Ltd.

Fleming, B. \& Fleming, J.P. 2009. A watershed conservation success story in Nepal: Land use changes over 30 years. Waterlines, 28 (1), 29-46. Doi:10.3362/1756-3488.2009.004.

Gautam, A.P., Shivakoti, G.P. \& Webb, E.L. 2004. A review of forest policies, institutions, and changes in the resource condition in Nepal. International forestry review, 6(2), 136-148. Doi: 10.1505/ifor.6.2.136.38397.

Gautam, A.P., Webb, E.L., Shivakoti, G.P. \& Zoebisch, M.A. 2003. Land use dynamics and landscape change pattern in a mountain watershed in Nepal. Agriculture, ecosystems \& environment, 99(1-3), 83-96.Doi: $\quad$ 10.1016/S01678809(03)00148-8.

GON, 2015. Development of Ecosystem based Sediment Control Techniques and Design of Siltation Dam to Protect Phewa Lake. Summary Report. Prepared By Forum for Energy and Environment Development (FEED) P. Ltd. for The Ecosystem Based 
Adaptation in Mountain Ecosystems (EbA) Nepal Project. Government Of Nepal, United Nations Environment Programme, United Nations Development Programme, International Union For Conservation Of Nature, and the German Federal Ministry for the Environment, Nature Conservation, Building And Nuclear Safety.

Heyojoo, B.P. \& Takhachhe, P. 2014. An Assessment of Lake Area Shrinkage through Geospatial Approach: Case study of Phewa Lake of Kaski District, Nepal.International Journal of Multidisciplinary and Current research, 2, 725-728.

Heyojoo, B.P., Timilsina, Y.P., Sharma, R.P.\& Karki, G.B. 2009. An Assessment of Sediment Sources from Rural Road Construction and Landslide at Phewa Lake Watershed of Kaski District, Nepal.

Javed, A., Khanday, M.Y.\& Ahmed, R. 2009. Prioritization of sub-watersheds based on morphometric and land use analysis using remote sensing and GIS techniques. Journal of the Indian society of Remote Sensing, 37(2), 261-274.Doi: 10.1007/s12524-009-0016-8.

Jorgensen, S.E. \& Volleweider, R.A. 1989. Guidelines of lake management. International Lake Environment Committee (ILEC), Shiga, Japan, voll.

Khanal, T. R. \& Bastola, K. R. 2005. Land Usel Land Cover Changes in Phewa Lake Watershed Area in Pokhara, Nepal. Paper Presented in Map Asia, Jakarta, Indonesia.

Lambin, E. F., Turner, B. L., Geist, H. J., Agbola, S. B., Angelsen, A., Bruce, J. W., Coomes, O.T., Dirzo, R., Fischer, G., Folke, C., George, P.S., Homewood, K., Imbernon, J., Leemans, R., Li, X. B., Moran, E. F., Mortimore, M., Ramakrishnan, $P$. S., Richards, J. F., Skanes, H., Stefeen, W., Stone, G. D., Svedin, U., Veldkamp, T. A., Vogel, C. \& Xu, J. C. 2001. The causes of land-use and land-cover change: moving beyond the myths. Global Environmental Change, 11(4), 261-269.

Lillisand, T.M., Kiefer, R.W.\& Andchipman, J.W. 2004. Remote Sensing and Image
Interpretation. John Wiley\&Sons, New York, USA. 31.

Mouat, D.A., Glenda, G.M. \& Lancaster, J. 1993. Remote Sensing Techniques in the Analysis of Change Detection. Geocarto International. 8 (2), 39-50. Doi:10.1080/10106049309354407.

Muzzini, E. \&Aparicio, G.2013.Urban Growth and Spatial Transition in Nepal.Washington D.C:World Bank.

Niraula, R.R., Gilani, H., Pokharel, B.K.\& Qamer, F.M. 2013. Measuring impacts of community forestry program through repeat photography and satellite remote sensing in the Dolakha district of Nepal. Journal of environmental management, 126, 20-29. Doi: 10.1016/j. jenvman.2013.04.006.

Omernik, J.M., Abernathy, A.R.\& Male, L.M. 1981. Stream nutrient levels and proximity of agricultural and forest land to streams. Some relationships. Journal of Soil Water Conservation,36(4), 227-231.

Paudel, B., Zhang, Y., Li, S. \& Wu, X. 2017. Spatiotemporal reconstruction of agricultural land cover in Nepal from 1970 to 2010. Regional Environmental Change, 17(8), 2349-2357.Doi: 10.1007/s10113-017-1164-y.

Paudel, K.P., Tamang, S. \& Shrestha, K.K. 2014. Transforming land and livelihood: Analysis of agricultural land abandonment in the Mid Hills of Nepal. Journal of Forest and Livelihood, 12(1), 11-19.

Paudel, N.S., Bastakoti, B.P., Karki, R. \& Bista, R. 2012. Drivers and dynamics of agrarian transformation in Nepal: Review of broader socio-economic issues around Nepalese agricultural development. Kathmandu. Forest Action Nepal.

Paudyal, K., Baral, H., Bhandari, S.P. \& Keenan, R.J. 2018. Design considerations in supporting payments for ecosystem services from community-managed forests in Nepal. Ecosystem services, $\quad 30, \quad$ 61-72.Doi:10.1016/j. ecoser.2018.01.016.

Paudyal, K., Baral, H., Putzel, L., Bhandari, S.P.\& Keenan, R.J. 2017a. Change in land use and ecosystem services 
delivery from community-based forest landscape restoration in the Phewa Lake watershed, Nepal. International Forestry Review, 19(4), 88-101.Doi: 10.1505/146554817822330524.

Paudyal, K., Putzel, L., Baral, H., Chaudhary, S., Sharma, R., Bhandari, S., Poudel, I.\& Keenan, R.J. 2017b. From denuded to green mountains: process and motivating factors of forest landscape restoration in Phewa Lake watershed, Nepal. International Forestry Review, 19(4), 75-87. Doi: 10.1505/146554817822330515.

Poudel, K. R. 2000. Changing in Land Use Pattern: A GIS base study of Pokhara Valley. Dissertation in M. A. Department of Geography Prithvi Narayan Campus, Pokhara.

Rawat, J.S. \& Kumar, M. 2015. Monitoring land use/cover change using Remote Sensing and GIS techniques: A case study of Hawalbagh block, district Almora, Uttarakhand, India. The Egyptian Journal of Remote Sensing and Space Science, 18(1), 77-84.Doi:10.1016/j. ejrs.2015.02.002.

Regmi, R.R.\& Saha, S.K. 2015. Impact assessment of land use land cover change on soil erosion status in Phewa Lake watershed of Nepal. International Journal of Current Engineering and Technology, 5(3), 1708-1717.

Rimal, B. 2011. Urban growth and land use/land cover change of Pokhara Sub-metropolitan city, Nepal. Journal of Theoretical \& Applied Information Technology, 26(2), 118-129.

Rimal, B., Baral, H., Stork, N.E., Paudyal, K. \& Rijal, S. 2015. Growing city and rapid land use transition: Assessing multiple hazards and risks in the Pokhara Valley, Nepal. Land, 4(4), 957-978.Doi: 10.3390/land4040957.

Rimal, B., Zhang, L., Keshtkar, H., Haack, B.N., Rijal, S. \& Zhang, P. 2018a. Land uselland cover dynamics and modeling of urban land expansion by the integration of cellular automata and markov chain. ISPRS International Journal of Geo-Information, 7(4), 154. Doi: 10.3390/ijgi7040154.
Rimal, B., Zhang, L., Keshtkar, H., Sun, X. \& Rijal, S. 2018b. Quantifying the spatiotemporal pattern of urban expansion and hazard and risk area identification in the Kaski District of Nepal. Land, 7(1), 37. Doi: 10.3390/land7010037.

Sadidy, J., Firouzabadi, P. Z.\& Entezari, A. 2009. The Use of Radarsat and Landsat Image Fusion Algorithms and Different Supervised Classification Methods to use Map Accuracy - Case study: Sari Plain-Iran.

Sharma, R.P. 2012. Sedimentation at Phewa Lake due to landslide and its impact on rural livelihood. Bulletin of Nepal Geological Society, 29, 73-78.

Shrestha, D.P. 1997. Assessment of soil erosion in the Nepalese Himalaya: a case study in Likhu Khola Valley, Middle Mountain Region. Land Husbandry, 2(1), 59-80.

Shrestha, D.P., Zinck, J.A. \& Van Ranst, E. 2004. Modelling land degradation in the Nepalese Himalaya. Catena, 57(2), 135156.Doi: 10.1016/j.catena.2003.11.003.

Sidhu, G.S., Das, T.H., Singh, R.S., Sharma, R.K., Jadaun, S.P.S., Ravishankar, T. \& Rao, B.R.M. 2000. Soil resource inventory of watersheds for land use planning- A GIS approach. Indian Journal of Soil Conservation, 28, 22-29.

Steffen, W. L., Walker, B. H., Ingram, J. S.\& Koch, G. W. 1992.Global change and terrestrial ecosystems: The operational plan. IGBP report no 21. Stockholm: International Geosphere-Biosphere Programme.

Sthapit, K. M. 1988. Flood control and Watershed Management, Paper presented at the National Workshop on River Training, Embankment Protection, 4 - 5 May 1988, HMG/N, UNDP/ILO, Kathmandu, Nepal.

Sthapit, K.M. \& Balla, M.K.1998. Sedimentation Monitoring of Phewa Lake, Survey Report submitted to ITTO/IOF Project.

Stohlgren, T. J., Chase, T. N., Pielke, R. A., Kittel, T.G. F.\& Baron, J.S.1998. Evidence that local land use practices influence regional climate, vegetation, and stream flow patterns in adjacent natural areas. Global Change Biology, 4, 495-504.

Tamang, S., Paudel, K.P.\& Shrestha, K.K. 2014. 
Feminization of agriculture and its implications for food security in rural Nepal. Journal of Forest and Livelihood, 12(1), 20-32.

Tamrakar, R.1993. A comparative study of land use change in the Shivapuri integrated watershed development area between 1981-1993. Dept. Of Soil Conservation and Watershed Management, Min. of Forest and Soil conservation, Nepal.

Tang, Z., Engel, B. A., Pijanowski, B. C.\& Lim, K. J. 2005. Forecasting land use change and its environmental impact at a watershed scale. Journal of Environmental Management,76(1), 3545.Doi:10.1016/j.jenvman.2005.01.006.

Turner II, B. L., Skole, D., Sanderson, S., Fisher, G., Fresco, l.\& Leemans, R. 1995.Land-use land-cover change science/research plan. IGBP global change report no 35 and HDP report no 7. Stockholm and Geneva: International GeosphereBiosphere Programme and the human dimension of global environmental change programme.

UNDESA, 2014. World Urbanization Prospects: 2014 Revision.New York:United Nations Department of Economic and SocialAffairs.http://esa.
un.org/unpd/wup/Final 2014-Report.pdf.

Wang, L., Lyons, J., Kanehl, P. \& Bannerman, R. 2001. Impacts of urbanization on stream habitat and fish across multiple spatial scales. Environmental management, 28(2), 255-266. Doi: $10.1007 /$ s0026702409.

Wang, L., Lyons, J., Kanehi, P., Bannerman, $R$. \& Emmons, E. 2000. Watershed urbanization and changes in fish communities in southeastern Wisconsin streams.Journal of the American Water Resources Association, 36(5), 11731189.Doi:10.1111/j.1752-1688.2000. tb05719.x.

White, M.D. \& Greer, K.A. 2006. The effects of watershed urbanization on the stream hydrology and riparian vegetation of Los Penasquitos Creek, California. Landscape and urban Planning, 74, 125-138.Doi:10.1016/j. landurbplan.2004.11.015.

Zampella, R. A., Laidig, K. J.\& Lowe, R. L. 2007. Distribution of diatoms in relation to land use and $\mathrm{pH}$ in blackwater coastal plain streams. Environmental Management, 39, 369-384.Doi:10.1007/s00267-0060041-0. 
Annex 1: Area Statistics of LULC for 2003 and 2010

\begin{tabular}{|l|l|l|l|l|l|}
\hline \multicolumn{1}{|c|}{ LULC classes } & \multicolumn{1}{|c|}{$\begin{array}{c}\text { Area (ha) in } \\
2003\end{array}$} & Area (ha) in 2010 & $\begin{array}{c}\text { Change in } \\
\text { LULC area (ha) }\end{array}$ & \% change & Remarks \\
\hline Agricultural land & 5179.86 & 6573.78 & 1393.92 & 11.63 & Increased \\
\hline Forest & 4963.05 & 3882.42 & -1080.63 & 9.21 & Decreased \\
\hline Barren land & 891.99 & 464.31 & -427.68 & 3.56 & Decreased \\
\hline Urban areas & 425.34 & 600.03 & 174.69 & 1.46 & Increased \\
\hline Water bodies & 529.29 & 468.99 & -60.3 & 0.5 & Decreased \\
\hline
\end{tabular}

Annex 2: Area Statistics of LULC for 2010 and 2018

\begin{tabular}{|l|l|l|l|l|l|}
\hline LULC classes & $\begin{array}{l}\text { Area (ha) in } \\
2010\end{array}$ & $\begin{array}{l}\text { Area (ha) in } \\
2018\end{array}$ & $\begin{array}{l}\text { Change in } \\
\text { LULC area(ha) }\end{array}$ & change & Remarks \\
\hline Agricultural land & 6573.78 & 4914.72 & -1659.06 & 7.83 & Decreased \\
\hline Forest & 3882.42 & 4565.88 & 683.46 & 5.9 & Increased \\
\hline Barren land & 464.31 & 1065.87 & 601.56 & 5.02 & Increased \\
\hline Urban areas & 600.03 & 993.33 & 393.3 & 3.28 & Increased \\
\hline Water bodies & 468.99 & 449.73 & -19.26 & 0.16 & Decreased \\
\hline
\end{tabular}

Annex 3: Change/no change matrix in percentage of 2003-2010

\begin{tabular}{|l|l|l|l|l|l|l|}
\hline \multicolumn{1}{|c|}{$\begin{array}{c}\text { Years } \\
\mathbf{2 0 0 3 / 2 0 1 0}\end{array}$} & \multicolumn{1}{|c|}{ Forest } & Urban areas & $\begin{array}{c}\text { Barren } \\
\text { land }\end{array}$ & $\begin{array}{c}\text { Water } \\
\text { bodies }\end{array}$ & $\begin{array}{c}\text { Agricultural } \\
\text { land }\end{array}$ & $\begin{array}{c}\text { Total area } \\
\text { in 2003 \% }\end{array}$ \\
\hline Forest & $28.76^{*}$ & 0.04 & 0.52 & 0.06 & 12.01 & 41.39 \\
\hline Urban areas & $* * * * *$ & $2.96^{*}$ & 0.27 & 0.04 & 0.28 & 3.55 \\
\hline Barren land & 0.01 & 0.8 & $1.12 *$ & 0.22 & 5.3 & 7.45 \\
\hline Water bodies & $* * * * *$ & 0.01 & 0.06 & $3.53 *$ & 0.81 & 4.41 \\
\hline Agricultural land & 3.62 & 1.2 & 1.9 & 0.06 & $36.43 *$ & 43.21 \\
\hline Total area in $2010 \%$ & 32.39 & 5.01 & 3.87 & 3.91 & 54.83 & $100 \%$ \\
\hline
\end{tabular}

NOTE: '*' represents the no change in area of specific LULC used.

\section{Annex 4: Change/no change matrix in percentage of 2010-2018}

\begin{tabular}{|l|l|l|l|l|l|l|}
\hline \multicolumn{1}{|c|}{$\begin{array}{c}\text { Years } \\
\mathbf{2 0 1 0 / 2 0 1 8}\end{array}$} & Forest & $\begin{array}{c}\text { Urban } \\
\text { areas }\end{array}$ & Barren land & $\begin{array}{c}\text { Water } \\
\text { bodies }\end{array}$ & $\begin{array}{c}\text { Agricultural } \\
\text { land }\end{array}$ & $\begin{array}{c}\text { Total area in } \\
\mathbf{2 0 1 0} \%\end{array}$ \\
\hline Forest & $28.29 *$ & 0.03 & 0.27 & $* * * * *$ & 3.79 & 32.38 \\
\hline Urban areas & $* * * * *$ & $4.51^{*}$ & 0.39 & 0.01 & 0.1 & 5.01 \\
\hline Barren land & 0.05 & 0.7 & $1.84^{*}$ & 0.07 & 1.22 & 3.88 \\
\hline Water bodies & 0.02 & 0.26 & 0.26 & $3.34 *$ & 0.03 & 3.91 \\
\hline Agricultural land & 9.72 & 2.78 & 6.14 & 0.33 & $35.85^{*}$ & 54.82 \\
\hline Total area in 2018\% & 38.08 & 8.28 & 8.9 & 3.75 & 40.99 & $100 \%$ \\
\hline
\end{tabular}

NOTE: '*' represents the no change in area of specific LULC used. 